\title{
Molecular Characterization of Sphyraena afra (Peters, 1884) From Coastal Waters of Lagos State, Nigeria
}

\author{
Caroline Ireti Ayo-Olalusi*1 ${ }^{1}$, Adedolapo Abeke Ayoade ${ }^{2}$ \\ ${ }^{I}$ Department of Biotechnology, Nigerian Institute for Oceanography and Marine Research, 3 Wilmot Street, \\ Victoria Island, Lagos, Nigeria \\ ${ }^{2}$ Department of Zoology, University of Ibadan, Ibadan, Nigeria
}

\begin{abstract}
Level of homogeneity and variation of S. afra populations collected from coastal waters of Lagos state were studied using random amplified polymorphic DNA (RAPD)-PCR amplification. Fish specimens obtained from Oshoroko, Orimedu, Lagos Lagoon, Ibese and Yovoyan stations were used for the experiment. DNA was isolated using salting out method from caudal fin of the fish and RAPD analysis was carried out with five $10 \mathrm{bp}$ - oligo- nucleotide random primers(RAPD). Four out of the five primers showed stable amplification and polymorphism with amplicons. A total number of 33 bands ranging from 250bp to 1000bp were analysed.A dendrogram from all the stations with clusters at various degree of coefficient was produced using PAlentological (PAST) software.The high level of similarity coefficient of fish species from all the coastal waters of Lagos state as all the characters cluster together indicates high genetic similarity within the population studied and no sub speciation in $S$ afra from coastal waters of Lagos state.This work could be considered as preliminary work on the biology of this species for its sustainable exploitation and culture purposes.
\end{abstract}

Keywords: Random amplified polymorphic DNA (RAPD), polymorphism, primers, Sphyraena afra, genetic similarity.

\section{Introduction}

Sphyraena species is an economically important fish species; whose population has not been characterized in the Nigerian coastal waters where it forms part of the major commercial catch. The fish commands high market value and high consumer acceptability as the fish is tasty and firm. Sphyraena afra is a candidate for marine culture and information on the genetic characterization of this fish is important to characterize the strains, the population and for the development of successful management program in the wild and culture in the coastal waters of Lagos state.

DNA marker technologies are not only the basis for genetic linkage mapping, but also for the analysis of genetic resources, strain differentiation, species differentiation, parentage identification, and preservation of genetic diversity and conservation of genetic integrity. DNA marker technologies arealready used routinely for stock identification in some farmed fish species(Beachamet al., 2000, 2005; Duchesne and Bernatchez, 2007).

Random Amplified Polymorphic DNA (RAPD) analysis is one of the modern marker techniques for studying genetic variability (Williams et al., 1990) and has been used to evaluate genetic diversity for species, subspecies and population/stock identification in tilapia (Bardakci and Skibinski, 1994), guppy (Foo et al., 1995), brown trout and Atlantic salmon (Eloet al., 1997), largemouth bass (Williams et al., 1998), Ictalurid catfishes (Liu and Dunham 1998), common carp (Bártfaiet al., 2003) and Indian major carps (Barman et al., 2003). Random Amplified Polymorphic DNA (RAPD) has all the advantage of PCR-based marker, with the added benefit that primers are commercially available and do not require prior knowledge of the target DNA sequence or gene organization. Multilocus amplifications can be separated electrophoretically on agarose gels and stained with ethidium bromide. RAPD has been used to characterize, determine genetic variability, distribution and diversity in fish in Nigeria. Ahmad et al. (2012) used RAPD markers to study the diversity and distribution of fishes of Gaji River, Bauchi state, Nigeria. Mojekwuet al. (2012), used RAPD markers to show the genetic variability of Tilapia in different water bodies in south west Nigeria and the result revealed high degree of genetic similarity within species using RAPD -PCR based technique. Megbowon and Bombata (2013) applied RAPD marker to characterize an unidentified cichlid, locally known as Wesafu. The result showed RAPD- PCR to be reliable as a typing tool for discriminating 'Wesafu' from other tilapia isolates in Epe Lagoon. The objectives of this study are to characterize the possible strains and access the degree of polymorphism ofSphyraena afra in coastal waters of Lagos state using DNA electrophoresis. 


\subsection{Sample collection}

\section{Materials And Methods}

Fish specimens obtained from Oshoroko, Orimedu, Lagos Lagoon, Ibese and Yovoyan stations were used for the experiment (Fig.1). The caudal fin was cut, placed in Eppendorf tube containing 90\% (v/v) absolute ethanol and stored in refrigerator until use. For complete extraction of DNA from fin a modified protocol using salt $(\mathrm{NaCl})$ without signs of DNA degradation and fragmentation was used and with a low contamination by protein and RNA. RAPD analysis was done on the fish samples from 5 different stations using 10 bp- oligonucleotide random primers (Table 1).

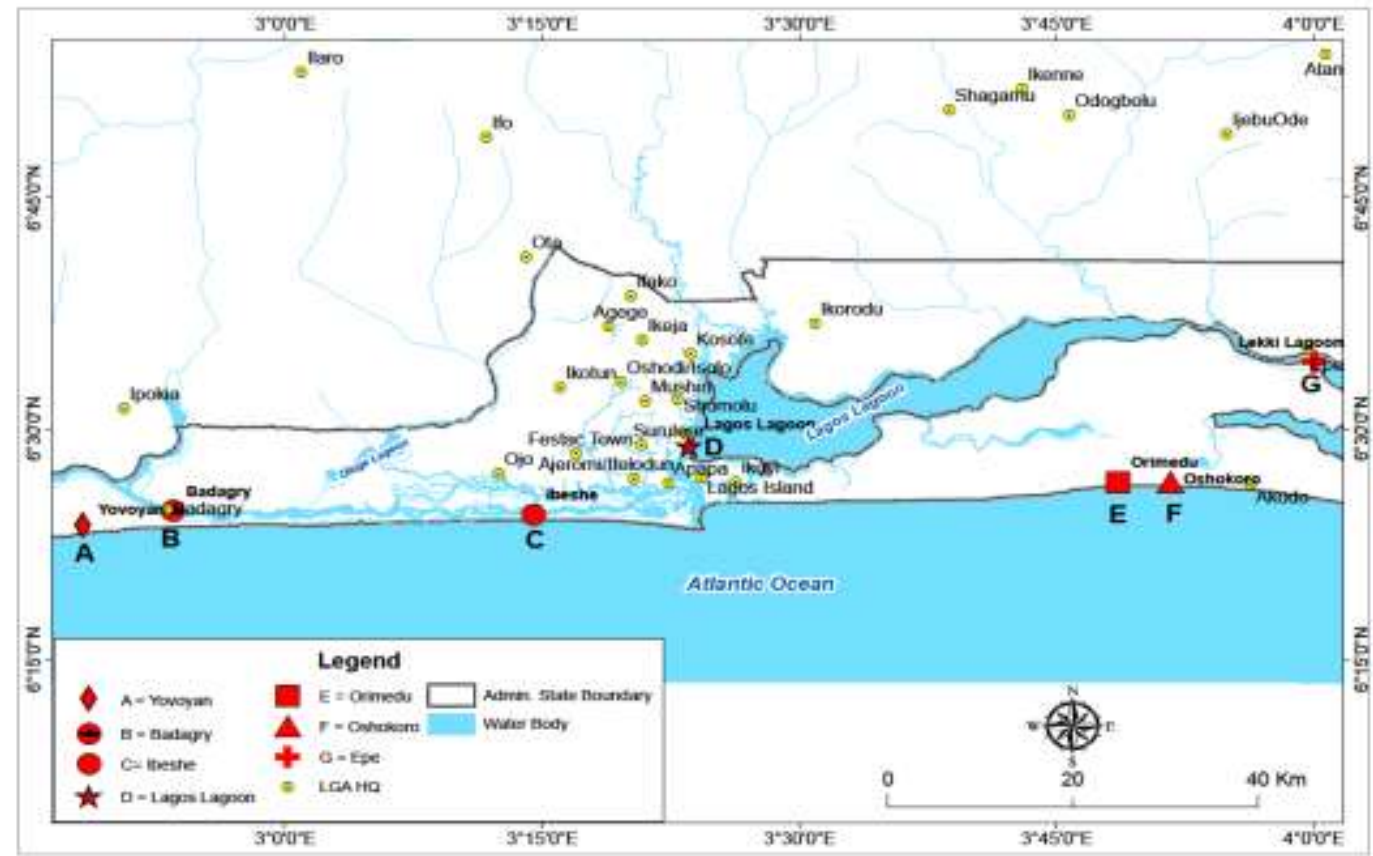

Fig. 1: Sampling sites

\subsection{DNA Extraction}

DNA was isolated using salting out method from caudal fin according to Lopera- Barreroet al. (2008). Caudal fins (approximately 2.4-5.5 g) of Sphyraena afra were placed in Eppendorf microtubes with absolute ethanol and maintained in a freezer at $-20^{\circ} \mathrm{C}$ in a test tube. Lysis buffer $(550 \mu \mathrm{l})$ containing $7 \mu \mathrm{l}$ of $200 \mathrm{ugml}^{-1}$ of proteinase $\mathrm{K}$ was added. The samples were incubated in a water bath at $50^{\circ} \mathrm{C}$ for 12 hours. Sodium chloride (660 $\mu \mathrm{l}$ of $5 \mathrm{M}$ ) was added and centrifuged at $12000 \mathrm{rpm}$ for $10 \mathrm{~min}$. The supernatant was transferred to another tube and $700 \mu \mathrm{l}$ of cold absolute ethanol was used to precipitate the DNA. The samples were incubated at $-20^{\circ} \mathrm{C}$ for 2 hrs. The DNA sample was centrifuged and washed with $700 \mu l$ of $70 \% \mathrm{v} / \mathrm{v}$ ethanol. The sample was resuspended in $80 \mu \mathrm{l} \mathrm{TE}$ buffer $(10 \mathrm{mM}$ of Tris $\mathrm{pH} 8.0$ and $1 \mathrm{mM}$ of EDTA).

Ribonuclease $\left(30 \mathrm{\mu gml}^{-1}\right)$ was added and samples were incubated in a water bath at $42^{\circ} \mathrm{C}$ for $4 \mathrm{hrs}$. This was stored in the freezer at $-20^{\circ} \mathrm{C}$ until ready to be used.

Table 1: Sequences of primers (10 bp- oligo- nucleotide) used in the amplification with RAPDs

\begin{tabular}{|l|l|l|l|}
\hline RAPD primerCode & Primer sequence 5 or 3 $^{\prime}$ & Nucleotide length & Source \\
\hline OPA-02 & TGCCGAGCTG & 10 -mers & Operon technology(USA) \\
\hline OPB-06 & TGCTCTGCCC & 10 - mers & Operon technology(USA) \\
\hline OPC-04 & CCGCATCTAC & 10 -mers & Operon technology(USA) \\
\hline OPD-06 & ACCTGAACGG & 10 -mers & Operon technology(USA) \\
\hline OPE-01 & CCCAAGGTCC & 10 -mers & Operon technology(USA) \\
\hline
\end{tabular}

\subsection{RAPD analysis and PCR conditions:}

The polymerase chain reaction mixtures $(25 \mu \mathrm{l})$ consisted of 0.125 unit of Taq DNA polymerase $(1.25$ Units), $0.5 \mu \mathrm{l}$ dNTPs, $0.2 \mu 1$ primers of RAPD $\left(100 \mathrm{pmol}^{-1} \mathrm{l}^{-1}\right)$, and $2.5 \mu 110 \mathrm{X}$ Taq DNA polymerase buffer, $5 \mu 1$ of

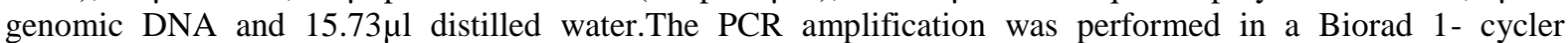
programmed for initial denaturation step at $94^{\circ} \mathrm{C}$ for 5 minutes followed by 45 cycles of denaturation at $94^{\circ} \mathrm{C}$ for 60 seconds, annealing at $45^{\circ} \mathrm{C}$ for 45 seconds and extension at $72^{\circ} \mathrm{C}$ for 1 min $30 \mathrm{secs}$; a final extension of $72^{\circ} \mathrm{C}$ for 5 minutes was carried out. The samples were cooled at $4^{0} \mathrm{C}$. The amplified DNA fragments were 
Molecular characterization of Sphyraena afra (Peters, 1884) from coastal waters of Lagos state, ..

separated on $1.5 \%(\mathrm{w} / \mathrm{v})$ agarose gel and stained with ethidium bromide. The amplified pattern was visualized on a UV transilluminator and photographed. Each RAPD assay was done three times to ensure reproducibility.

\subsection{Agarose gel electrophoresis:}

Agarose gel $(1 \% \mathrm{w} / \mathrm{v})$ was prepared by dissolving $1.7 \mathrm{~g}$ of agarose powder in $170 \mathrm{ml}$ of $1 \mathrm{xTBE}$ and warmed in a microwave oven for $4 \mathrm{~min}$ at $100{ }^{\circ} \mathrm{C}$. After melting, and the gel was cooled to about $60{ }^{\circ} \mathrm{C}$ for 10 min before adding $10 \mu \mathrm{l}$ of ethidium bromide $\left(10 \mathrm{mg} \mathrm{ml}^{-1}\right)$ and the gel was poured into the gel bed (tank). The slot former (comb) was placed in the agarose gel and allowed to sit for 30 minutes until the gel solidified and comb removed. Orange $G$ dye was added to increase the density of the DNA samples to make 'submarine' loading of the sample into the well of the gel much easier. With the aid of a micro pipette, $2 \mu 1$ of DNA was loaded into the well and connected to electricity source at $70 \mathrm{~V}$ for $2 \mathrm{hrs}$. First and second wells contained DNA marker (M) and a negative control (O). Current was allowed to pass through at $70 \mathrm{~V}$ for $1 \mathrm{hr} .30$ minutes. After the electrophoresis the gels were stained for 30 minutes with ethidium bromide and viewed with UV transilluminator and the pictures taken.

\subsection{Measurement of DNA purity and quality}

The yield of DNA was measured using a UV-spectrophotometer at $260 \mu \mathrm{m}$. The purity of DNA was determined by calculating the ratio of absorbance at $260 \mathrm{~nm}$ to that of $280 \mathrm{~nm}$ (Sambrooket al., 1989). The DNA concentration was determined by the formula:

DNA concentration $=\mathrm{OD}_{260} \times 50 \mu \mathrm{g} / \mathrm{ml} \mathrm{X}$ dilution factor $($ Linaceroet al., 1998)

\subsection{RAPD Amplification.}

\section{Result}

Plates 1, 2, 3 and 5 showed stable amplification and polymorphism while the remaining Plate 4showed unstable amplification or low reproducibility from the 5 primers used. RAPD OPA 02 had 11 bands between $250 \mathrm{bp}$ to $1000 \mathrm{bp}$ (plate 1).RAPD OPB 06 with 8 bands between $250 \mathrm{bp}$ to $1000 \mathrm{bp}$ (plate 2). RAPD OPC 04with -loci produced 7 bands between $250 \mathrm{bp}$ to $750 \mathrm{bp}$ (plate 3). RAPD OPD 06 had very poor reproducibility, with no loci or blurred loci (plate 4). RAPD OPE 01 with loci produced 7 bands 500bp to 1000bp (plate 5).

\subsection{Gel Scoring and data analysis}

DNA bands identified were scored as 1 when present or 0 when absent in each fragment pattern. Unambiguous and reproducible bands were used in analysis of gels. These data were used to calculate genetic distance using Jaccard coefficient similarity matrices. The data was subjected to unweighted pair-group method for arithmetic (UPGMA) cluster analysis using PAST (Paleontological statistics) software to generate a dendrogram with average linkages procedure.

\subsection{Phylogenetic analysis}

A dendrogram with clusters at various degree of coefficient was produced using PAST software as seen in Fig. 2. The dendrogram showed two clusters A and B at genetic distance 0.35 . Cluster A contained only Ib-1 and La-2 while cluster B contained two sub clusters (sub cluster 1 contained Yo-2 and Os-1 while sub cluster II contained Os-2, Ib- 2, La-1, Or-2, Yo-1 and Or-1) at 0.3 genetic distance. The dendogram also revealed samples Os-2, Ib-2, La -1, and Or-2 to be the closest among the samples evaluated as revealed by RAPD markers used with a genetic distance zero. A cluster was formed between samples from all the station indicating a high level genetic similarity.

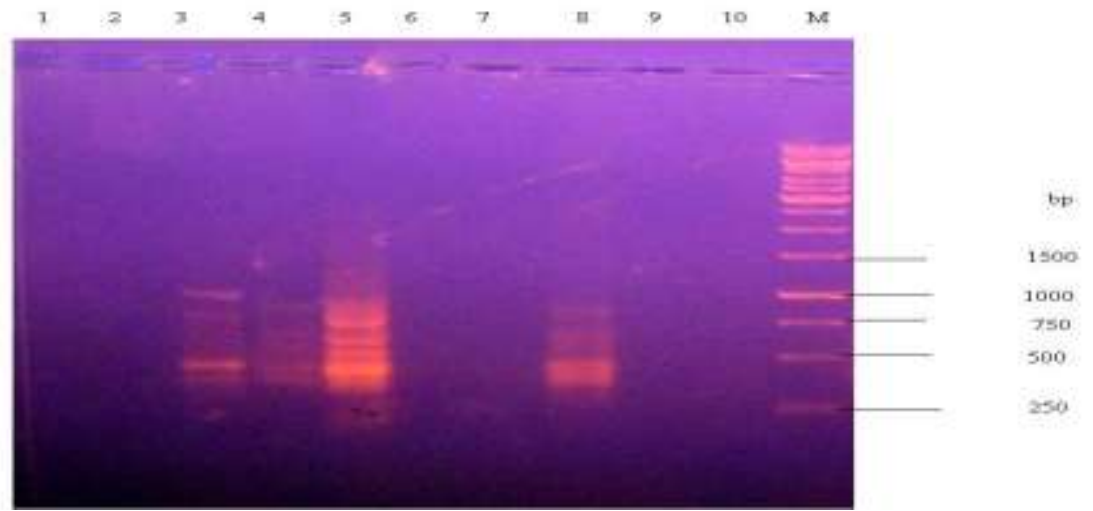

Plate 1: Amplification results of primer OPA 02 (TGCCGAGCTG) in Sphyraena afra from all the stationsOshoroko (1-2), Yovoyan (3-4), Ibeshe (5-6), Lagos lagoon (7-8) and Orimedu (9-10) 


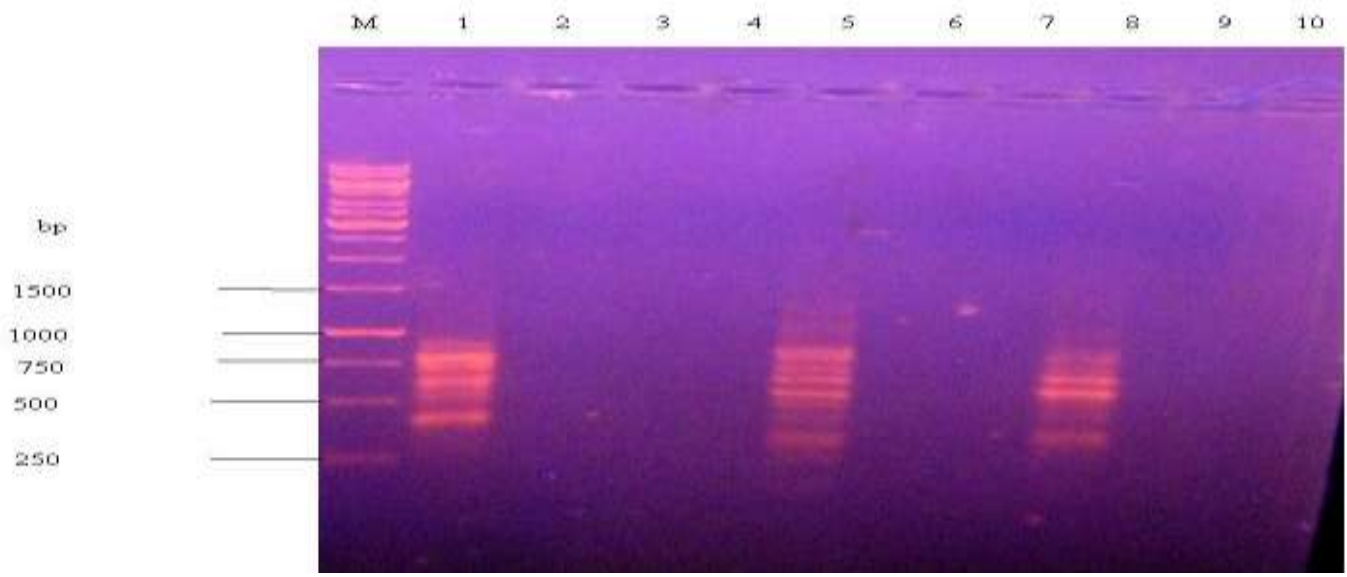

Plate 2: Amplification results of primer OPB 06 (TGCTCTGCCC) in Sphyraena afra from all the stationsOshoroko (1-2), Yovoyan (3-4), Ibeshe (5-6), Lagos lagoon (7-8) and Orimedu (9-10)

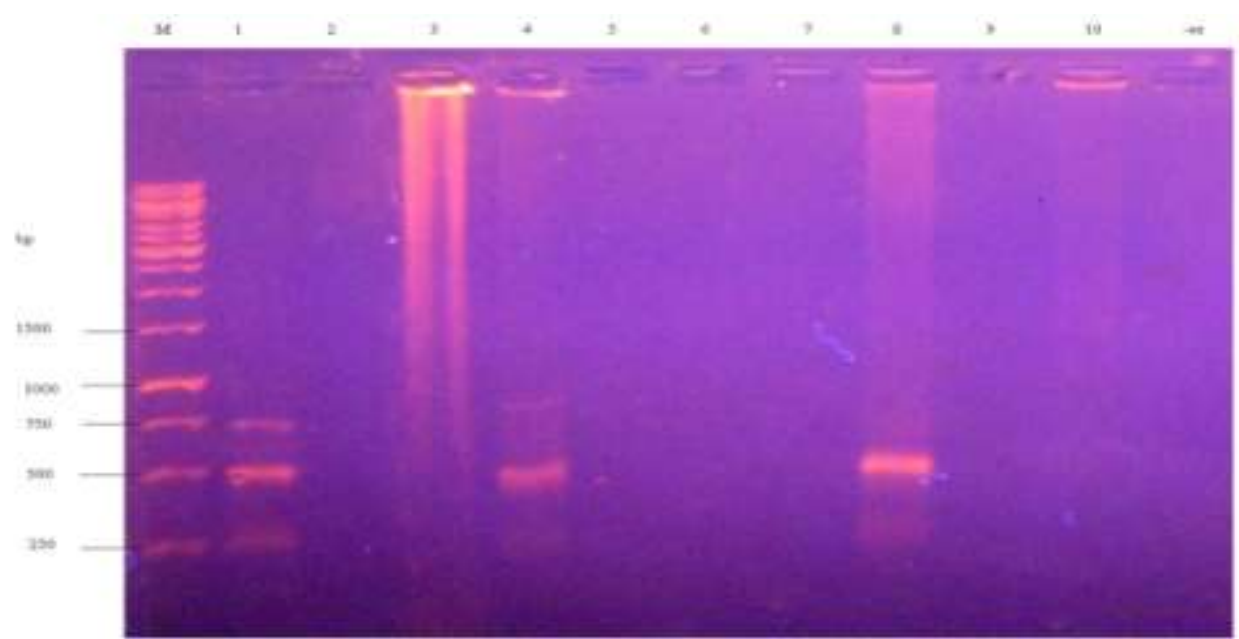

Plate 3: Amplification results of primer OPC 04 (CCGCATCTAC) in Sphyraena afra from all the stationsOshoroko (1-2), Yovoyan (3-4), Ibeshe (5-6), Lagos Lagoon (7-8) and Orimedu (9-10)

1

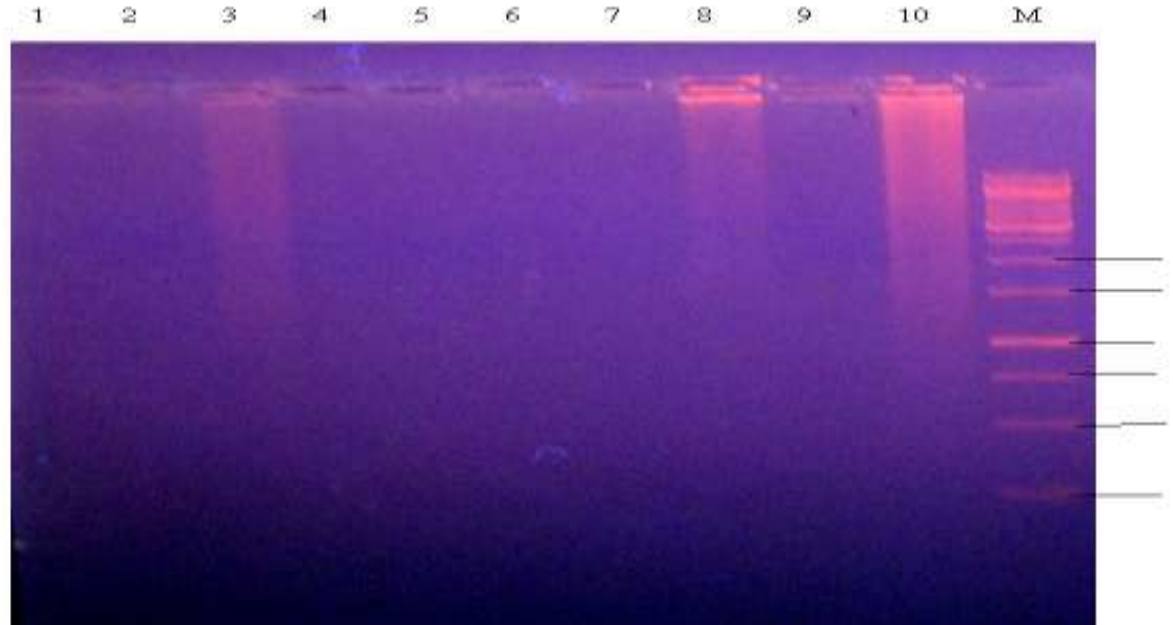

Plate 4: Amplification results of primer OPD 06 (ACCTGAACGG) in Sphyraena afra from all the stationsOshoroko (1-2), Yovoyan (3-4), Ibeshe (5-6), Lagos Lagoon (7-8) and Orimedu (9-10) 


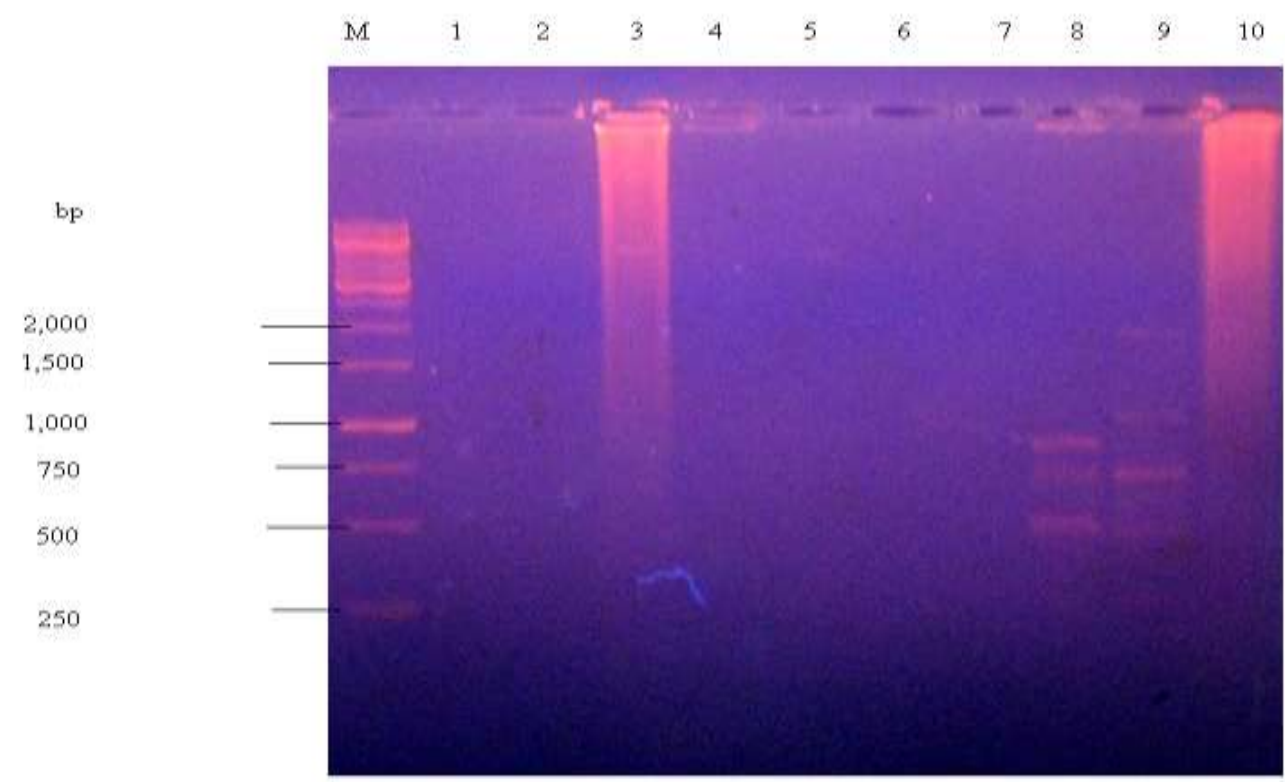

Plate 5: Amplification results of primer OPE 01 (CCCAAGGTCC) in Sphyraena afra from all the stationsOshoroko (1-2), Yovoyan (3-4), Ibeshe (5-6), Lagos Lagoon (7-8) and Orimedu (9-10)

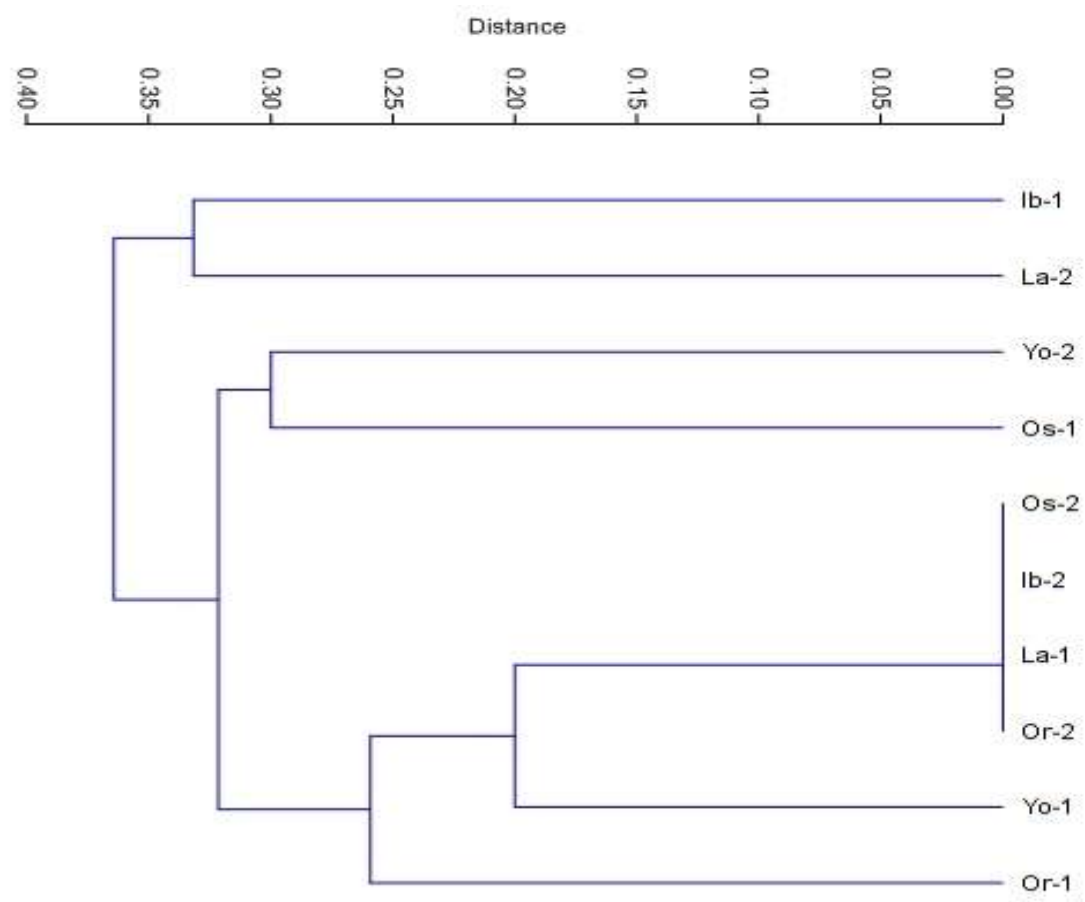

Figure 2: Dendrogram depicting the degree of relationship of Sphyraena afra from Oshoroko (Os), Yovoyan (Yo), Ibeshe (Ib), Lagos Lagoon (La) and Orimedu (Or) stations.

Keys:

Ib-1 = Ibeshe fish sample 1 La-1= Lagos lagoon fish sample 1 Yo-1= Yovoyan fish sample 1 Os-1= Oshoroko fish sample 1 Or-1= Orimedu fish sample 1
Ib-2 = Ibeshe fish sample 2

La-2= Lagos lagoon fish sample 2

Yo-2 $=$ Yovoyan fish sample 2

Os-2= Oshoroko fish sample 2

Or-2= Orimedu fish sample 2 


\section{Discussion}

Genetic diversity or variation and its measurement have vital importance on interpretation, understanding and management of populations and individuals. It can be asserted also that RAPD - PCR is a useful tool for estimating the genetic variability and degree of similarity among fish species as been reported by other workers (Barman et al., 2003; Lopera - Barreroet al., 2006, Mojekwuet al., 2012; Megbowon and Bombata, 2013).RAPD bands in this study were always unstable bands generated with each primer because of production of one or more copies of DNA per genome or may be attributed to the varying of the annealing process between primer and the DNA. Bielawkiet al. (1995) reported that this problem of mixed bands revealed the well-known sensitivity of PCRs for amplification. RAPD fragment generated by primer OPD 06 showed poor reproducibility with no loci or blurred among fish studied may have annealed to variable sequences which is of great use for differentiation of much related species. Not all variation at RAPD loci should be detectable simply in terms of the presence and absence of a given band, and not all mutation will necessarily lead to shift from presence or absence (or vice versa). However, in RAPD fragment generated by other primers with stable amplification and polymorphism, their sequences may be considered as more conserved sequences which are more useful in higher taxonomic levels and evolutionary relationship. These results are in agreement with Bardkci and Skibinski (1994) stated that, pattern of similarities and differences between population of three species of tilapia showed broad agreement across primers and the overall similarity level varied between primers.The high level of similarity coefficient of fish species from all the coastal waters of Lagos state as all the characters cluster together (phylogenetic tree) indicates high genetic similarity within the population studied.

\section{Conclusion}

In this study polymorphic DNA bands were identified based on their presence or absence which could be used in species differentiation and to detect hybridization or species speciation. No sub speciation in S. afra from coastal waters of Lagos state. The sensitivity of RAPD technique with no prior knowledge of the genome play an important role in detection of high genetic similarity observed within the population studied. Further studies with some sensitive technique such as restriction fragment polymorphism, amplified fragment length polymorphism and other sequence techniques are essential to clarify and confirm genetic relationships of this valuable fish species. However, this present study may serve as reference point for other fish species from the family sphyraenidae or other families for future examination of genetic variation between fish species that are economically and commercially important.

\section{Acknowledgement}

Authors are thankful to the Nigerian Institute for Medical Research for providing some of the facilities used and Nigerian Institute for Oceanography and Marine Research for research materials.

\section{References}

[1]. Ahmad J.N., Azizah, M.N., Adikwu, I.A., Istifanus, W. A.,Abalis,G.E and Muchlisin,Z.A (2012). Diversity and distribution of fishes of Gaji River, Bauchi state Nigeria. Advances in Environmental sciences-Internationaljournal of the bioflux society vol 4, issue 2. Pp.50 -54.

[2]. Bardakci, F. and Skibinski, D.O.F (1994). Application of the RAPD techniquein tilapia fish: species and subspecies identification Heredity 73:117 - 123 .

[3]. Barman, H.K, Barat, A., Ydav, B.M., Banerjee, S., Meher, P.K., Reddy, P.V. and Jana, R.K. (2003). Genetic variation between four species of Indian carp as revealed by random amplified polymorphic DNA assay. Aquaculture 217: 115 - 123.

[4]. Bártfai, R., Egedi, S., Yue, G.H., Kovács, B., Urbányi, B., Tamás, G., Horváth, L. and Orbán, L. (2003). Genetic analysis of two common carp broodstocks by RAPD

[5]. Beacham, T.D., Hay, D.E. and Le, K.D. (2005). Population structure and stock identification of Eulachon (Thaleichthyspacificus), an anadromous smelt in the Pacific Northwest. Marine Biotechnology, 7: 363 - 72.

[6]. Beacham, T.D., Pollard, S. and Le, K.D. (2000). Microsatellite DNA population structure and stock identification of steelhead trout (Oncorhynchus mykiss) in the Nass and Skeena rivers in northern British Columbia. Marine Biotechnology, 2: 587 - 600.

[7]. Bielawski, J.P.; Noack, K. and Pumo, D.E. (1995). Reproducible amplification of RAPD markers from vertebrate DNA. Biotechniques. 18: 856-860.

[8]. Duchesne, P. \&Bernatchez, L. (2007). Individual-based genotype methods in aquaculture, In: Aquaculture Genome Technologies, Blackwell Publishing. Ames, 1A, 96: 87 - 98.

[9]. Elo K., Ivanoff S., Jukka A., Vuorinen J. and Piironen, J. (1997). Iheritance of RAPD markers and detection of interspecific hybridization with brown trout and Atlantic salmon. Aquaculture 152: 55-56

[10]. Foo, C.I., Dinesh K.R., Lim T.M. Chan, W.K., Phang, V.P.E. (1995): Inheritance of RAPD markers in the guppy fish, Poecilia reticulate, Zoological science, 12:535.

[11]. Liu Z.J and Dunham, R.A. (1998). Genetic linkage and QTL mapping of Ictalurid catfish. Ala.Agric.Exp. Stn.Bull., 321:1-19

[12]. Linacero, R.. Rueda J. and Vazquez, A.M. (1998). Quantifying of DNA. Karp, A., P.G. Isaac and D.S Ingram (Eds.). Molecular Tools for Screening Biodiversity: Plants and Animals. Chapman and Hall. London, Weinleim, New York, Tokyo, Melbourne, Madras, pp: 18-21.

[13]. Lopera- Barrero, N.M., Povh, J.A., Ribeiro R.P., Gomes P.C, Jacometo C.B, Da Silva Lopes T (2008). Comparison of DNA extraction protocol of fish fin and larvae samples modified salt (Nacl) extraction. Cien. Inv. Agri. 35 (1): 65-74.

[14]. Megbowon I. and Fashina-Bombata, H.A. (2013): Molecular characterization of anUnidentified Cichlid. Commonly called "Wesafu", using RAPD markers. IOSR Journal of Environmental Science, Toxicology and Food Technology. 5 (2) 22-26. 
[15]. Mojekwu, T.O, Oguntade, O.R, Oketoki T.O and Usman A.B. (2012). Genetic variability of Tilapia in different water bodies using RAPD markers. Proceedings of the $25^{\text {th }}$ Annual Conference of the Biotechnology Society of Nigeria. Held at National Open University, Abuja.

[16]. Mojekwu, T.O, Oguntade, O.R, Oketoki T.O, Usman A.B. and Omidiji (2013): Molecular characterization of Tilapia in different water bodies using RAPD markers. African Journal of Applied Biotechnology, 1 (1): 1-12

[17]. Sambrook, J. Fritsch E.F and Maniatis, T. (1989). Molecular Cloning: A laboratory Manual, $2^{\text {nd }}$ Edn. Cold Spring Harbor Laboratory Press. Cold Spring Harbor, N.Y.

[18]. Williams J.G.K, Kubelik A.R., Livak, K.J., Rafalski J.A. and Tingel, S.V. (1990). DNA Polymorphic amplified by arbitarary primers are useful as genetic markers. Nuclei Acid Research, 18: 6531-6535

[19]. William, P., Young, P.A., Wheeler, V.H., Coryell, P.K., Gary, H. and Thorgaard, G.H. (1998). A Detailed Linkage Map of Rainbow Trout Produced Using Doubled Haploids. Genetics, 148: 839-850. 